\title{
CURRENT STATE, IMPROVEMENTS AND LATEST TRENDS IN COAL PREPARATION IN POLAND
}

\author{
Wiesław S. BLASCHKE ${ }^{1}$, Ireneusz BAIC ${ }^{1}$, J ózef SZAFARCZYK ${ }^{1}$ \\ ${ }^{1}$ Institute Mechanised Construction \& Rock Mining, Branch in Katowice
}



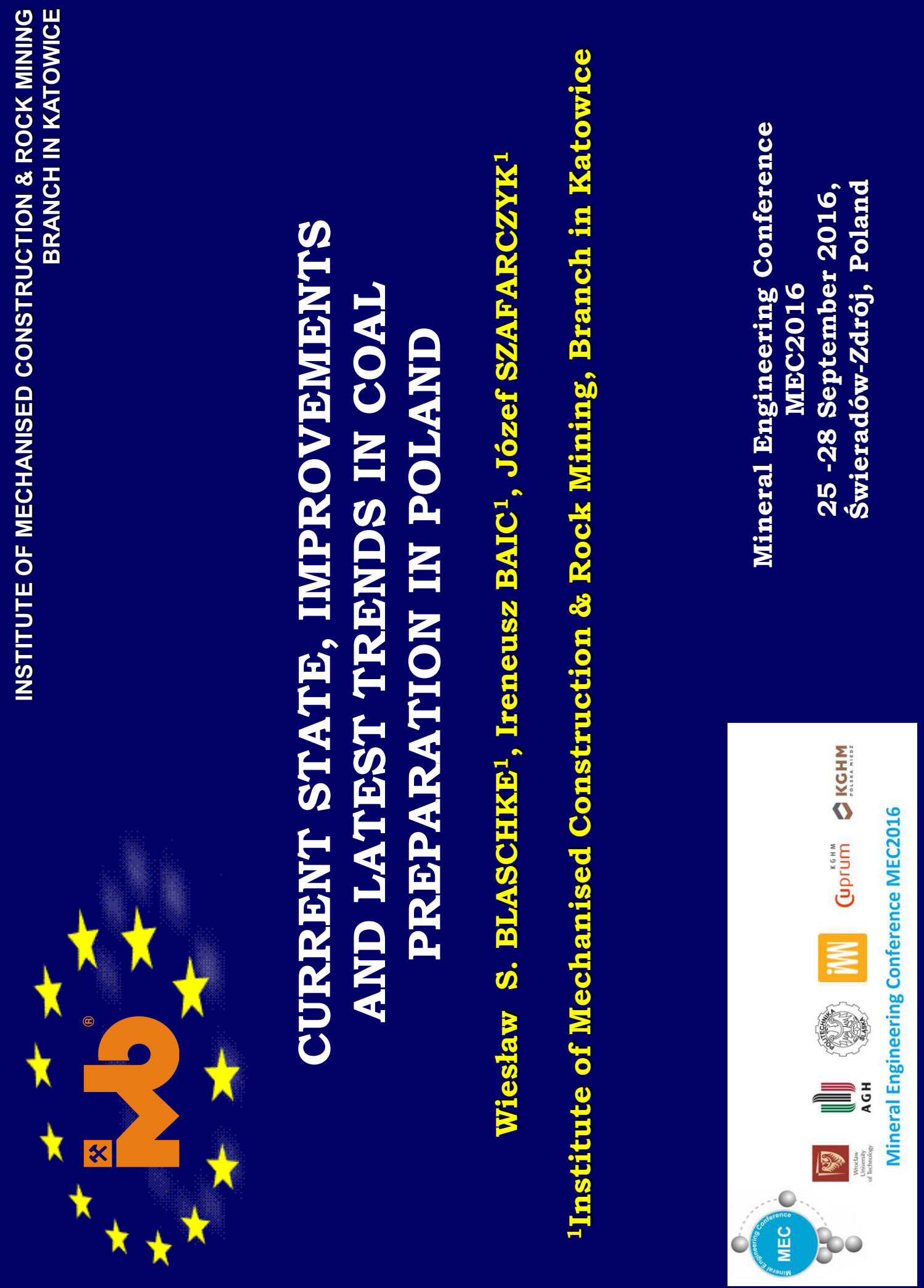


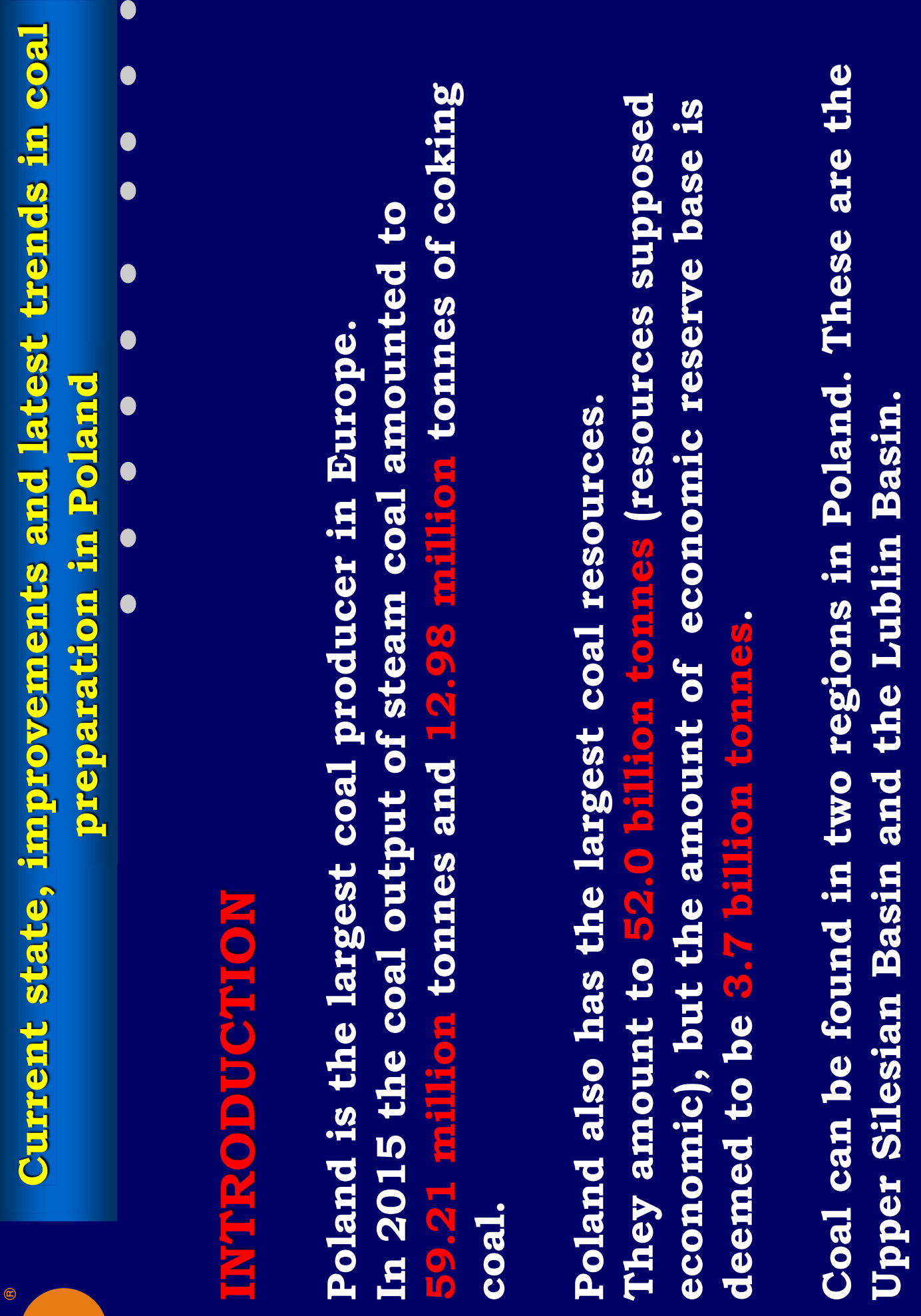

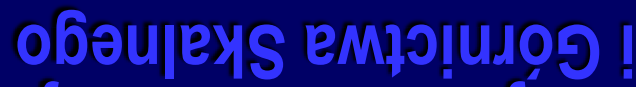

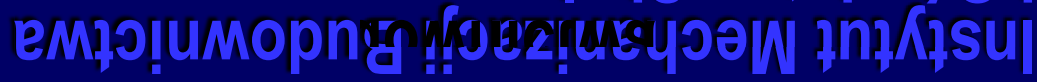



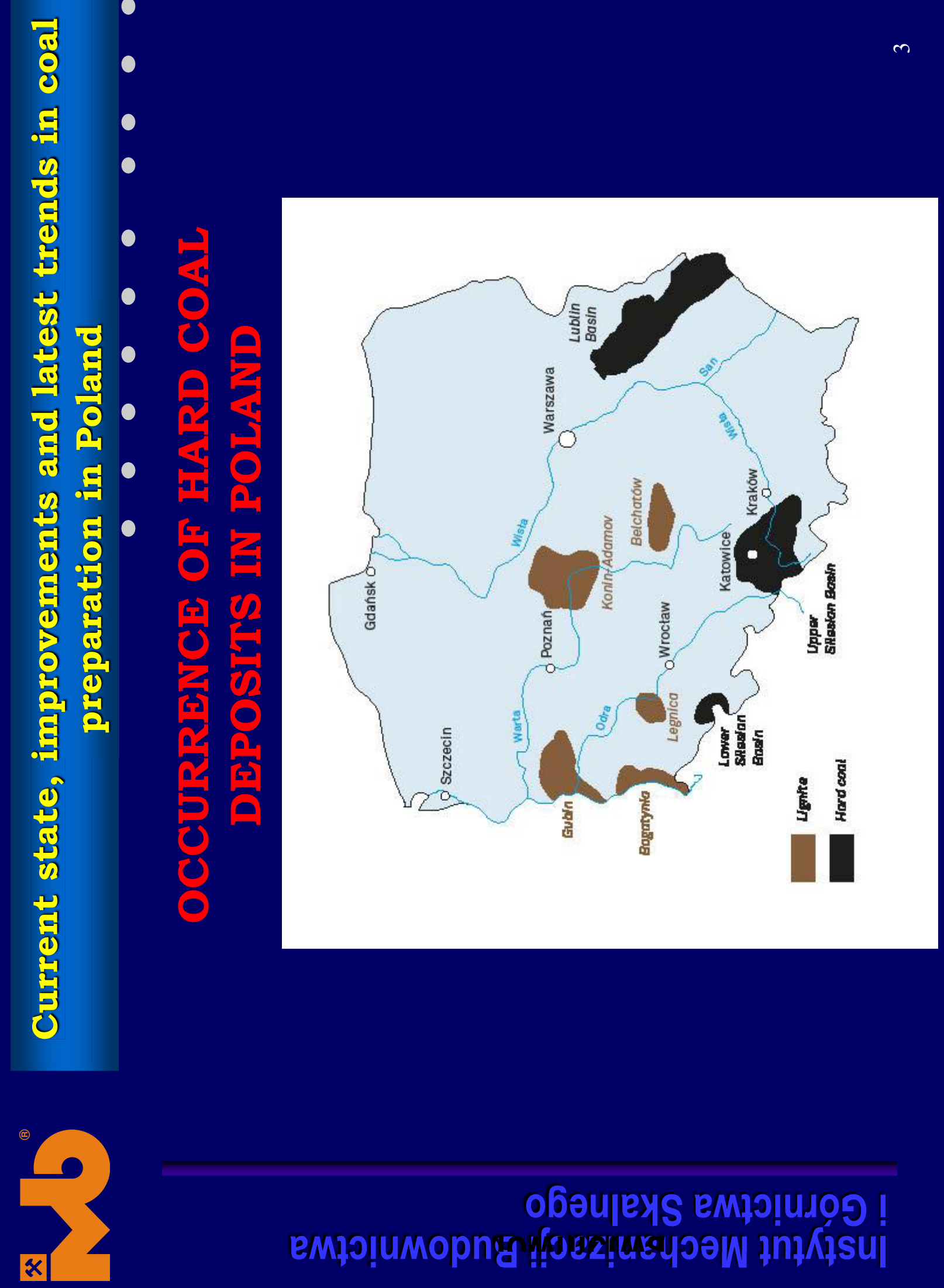

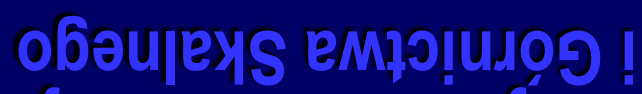

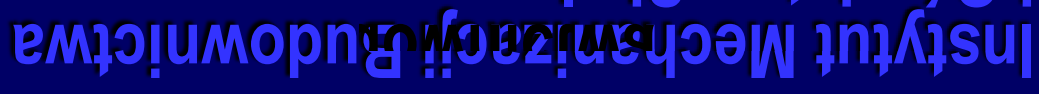




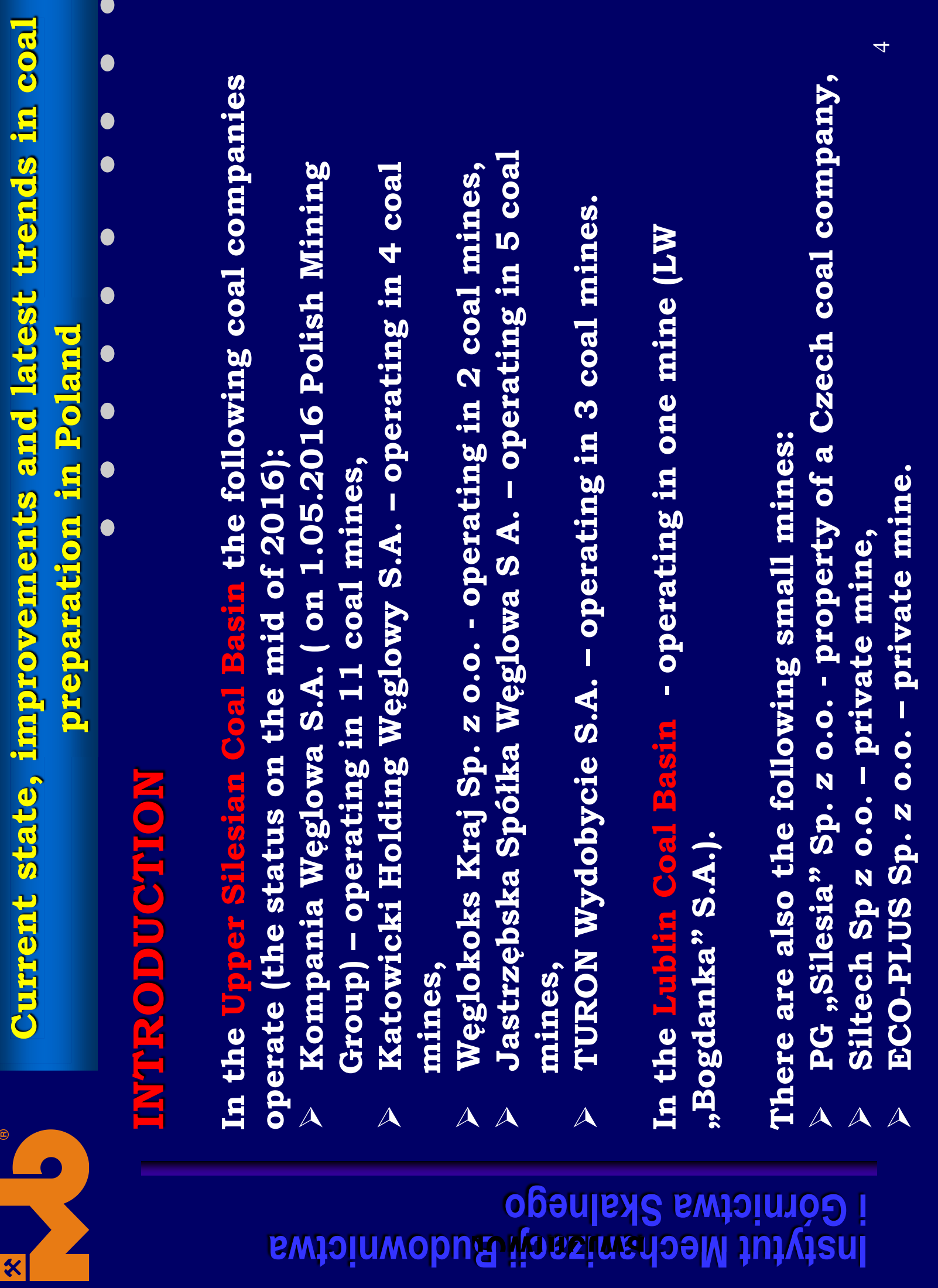




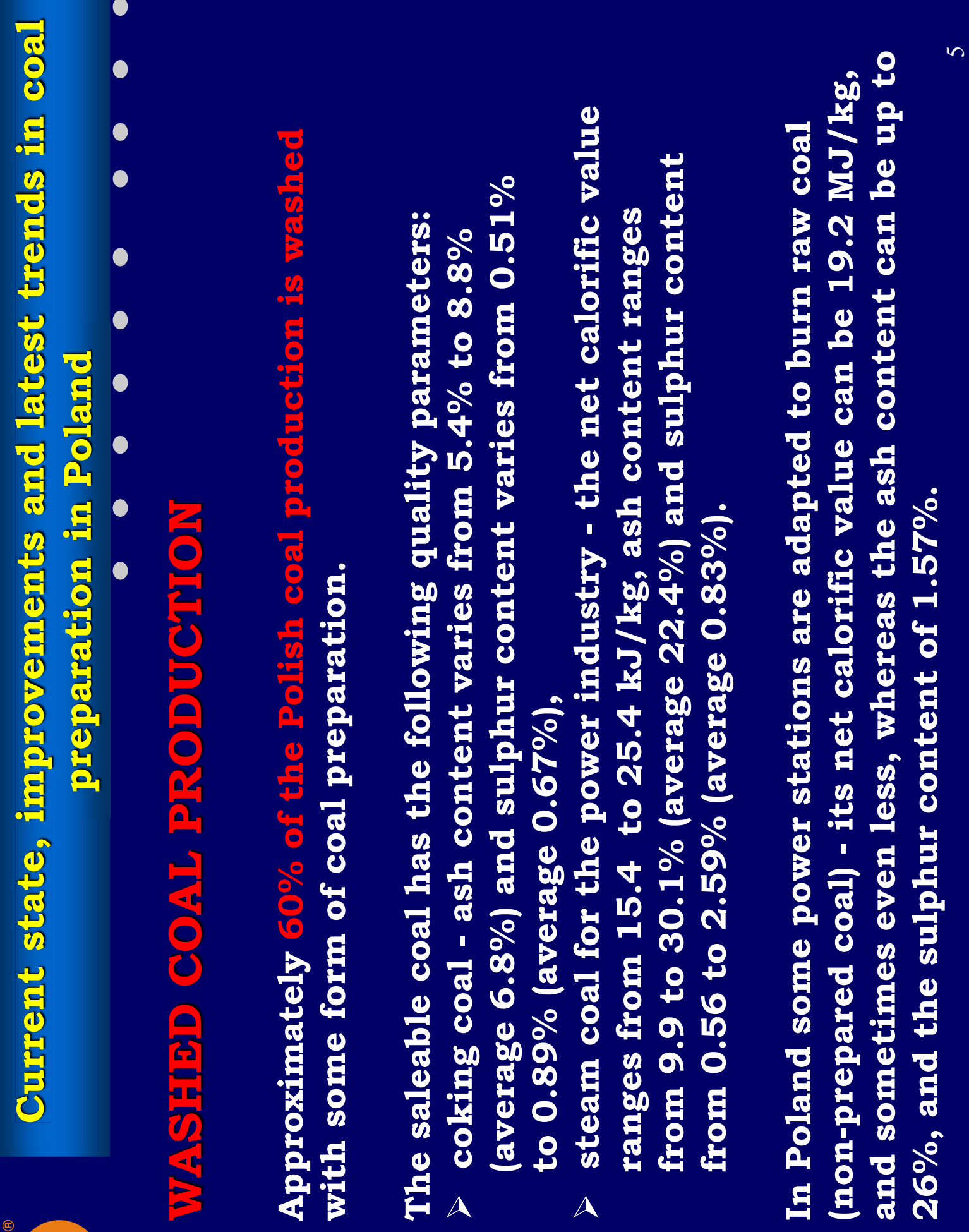




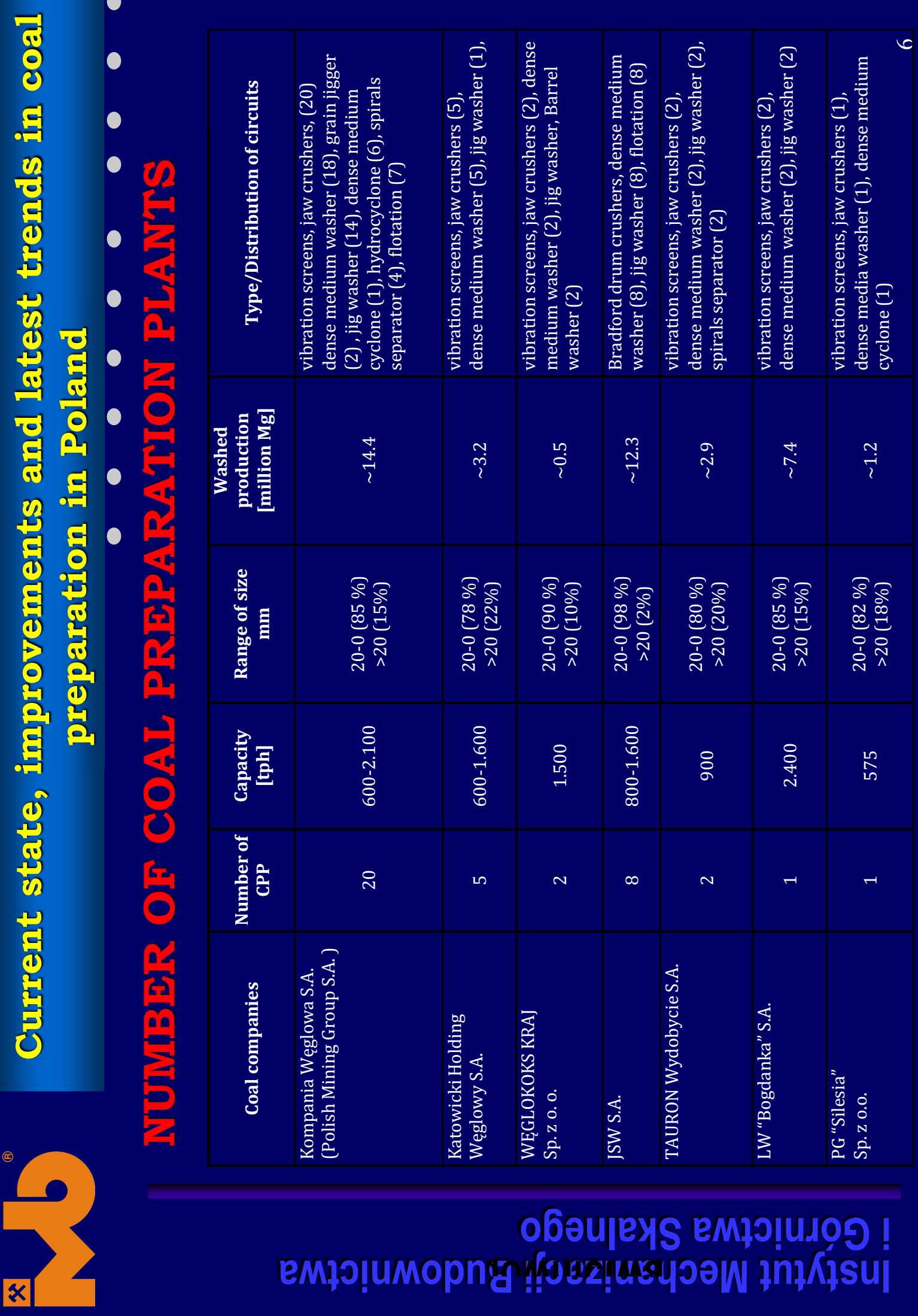




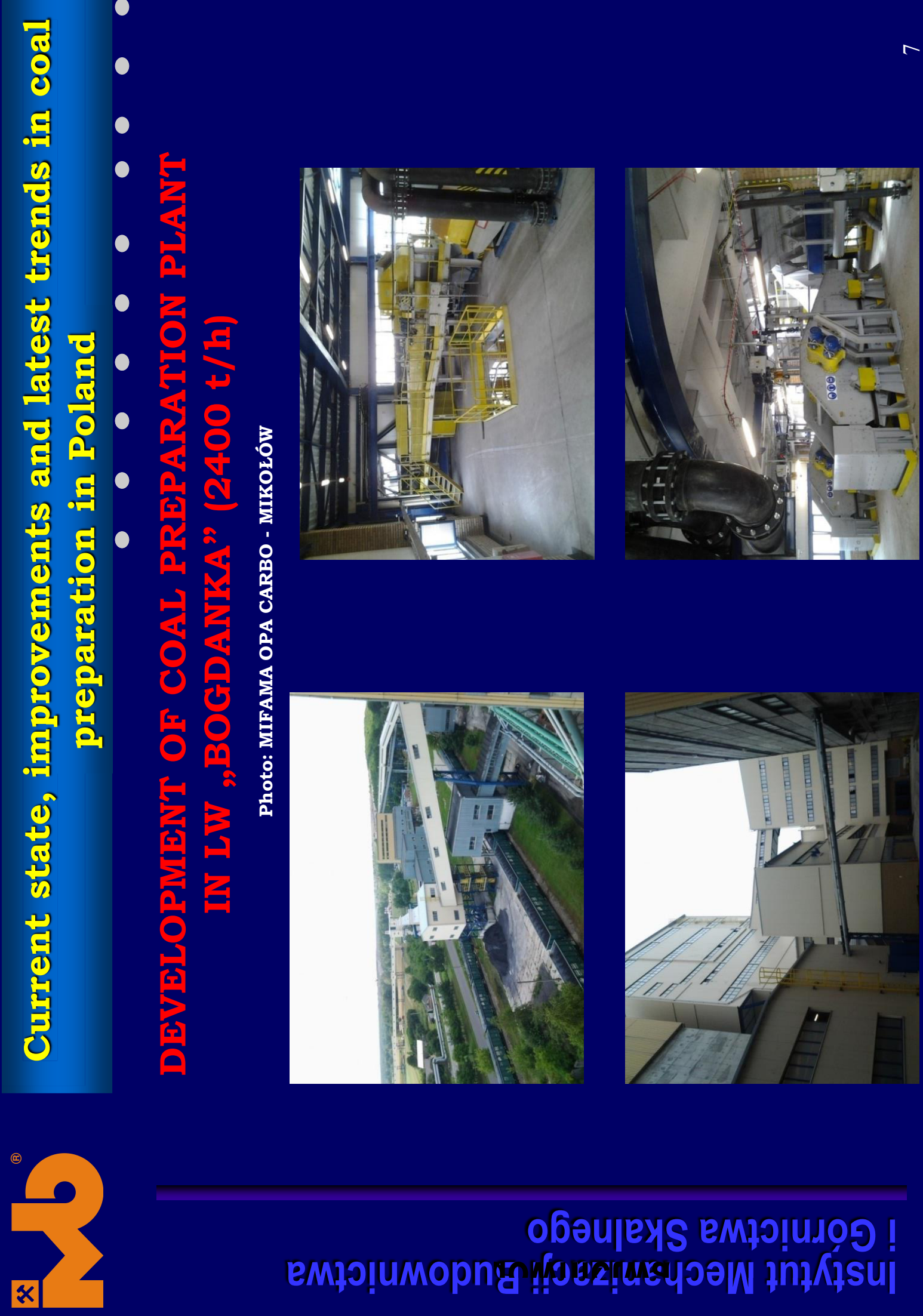



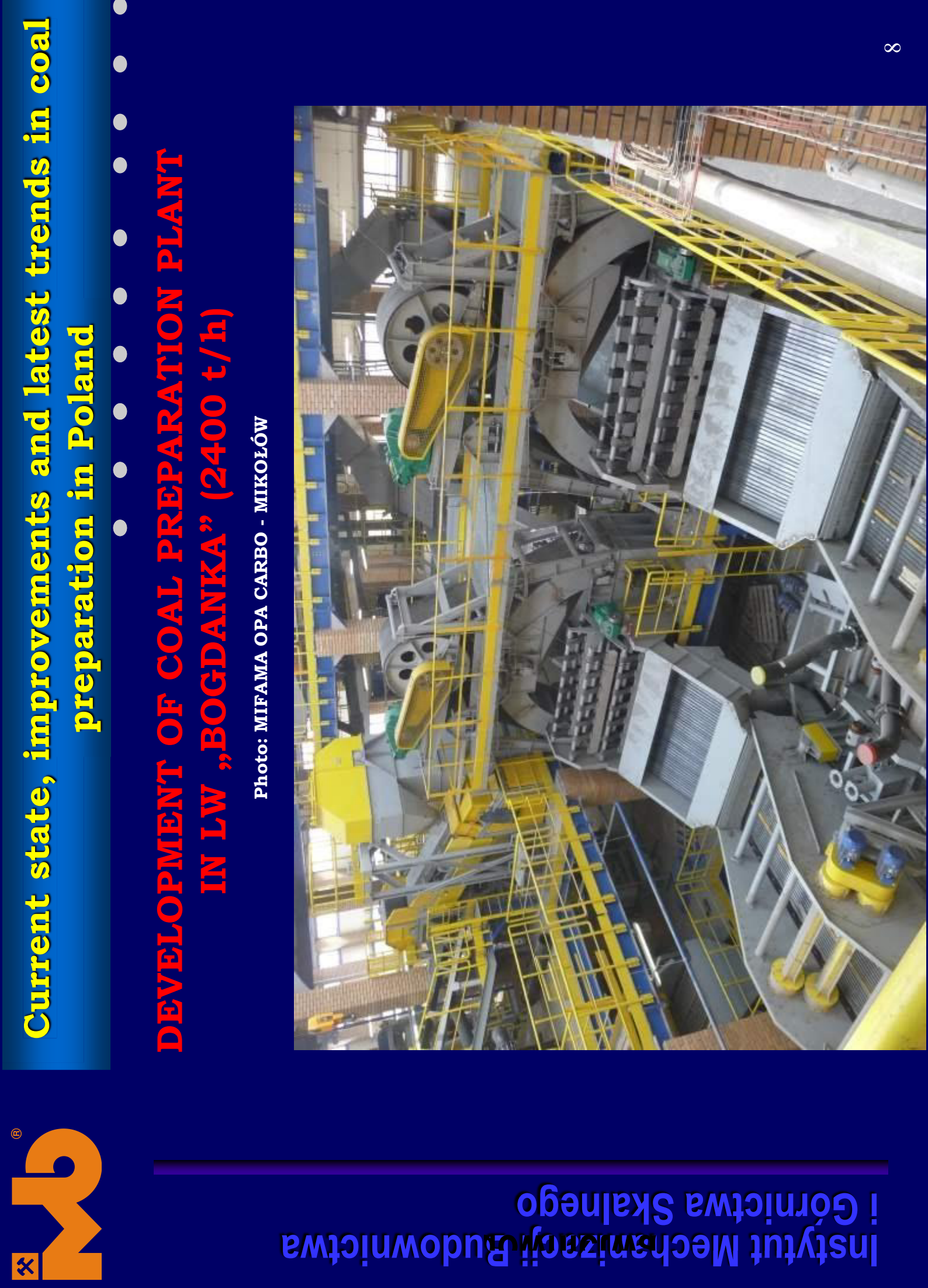

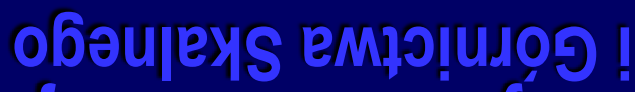

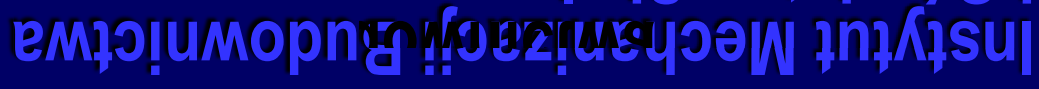



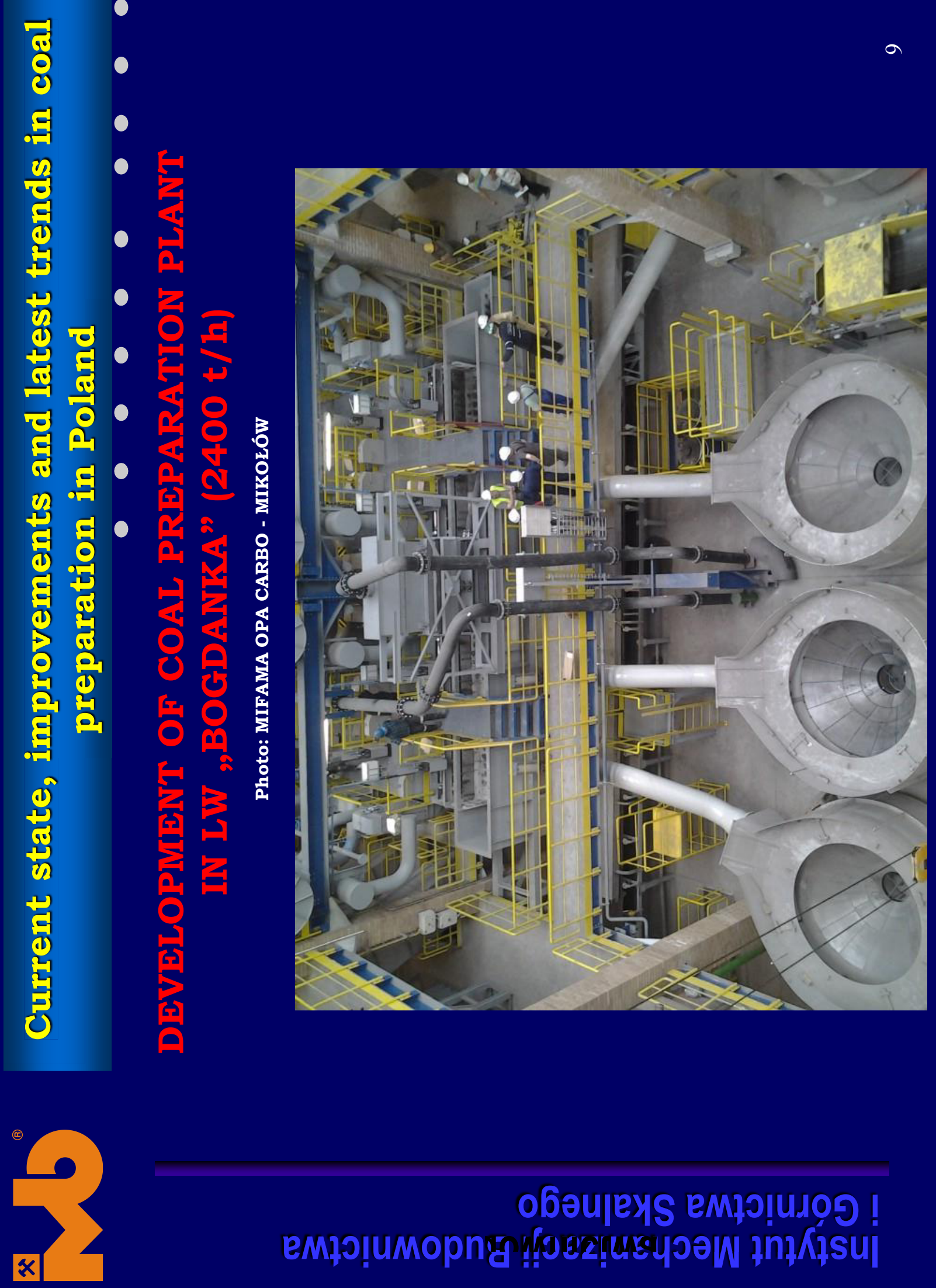

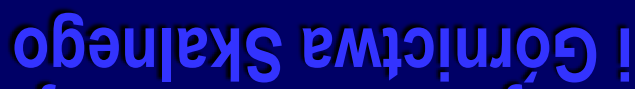

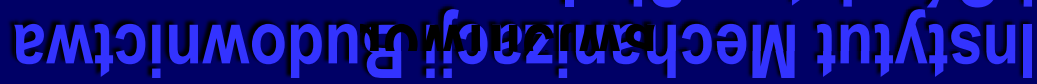



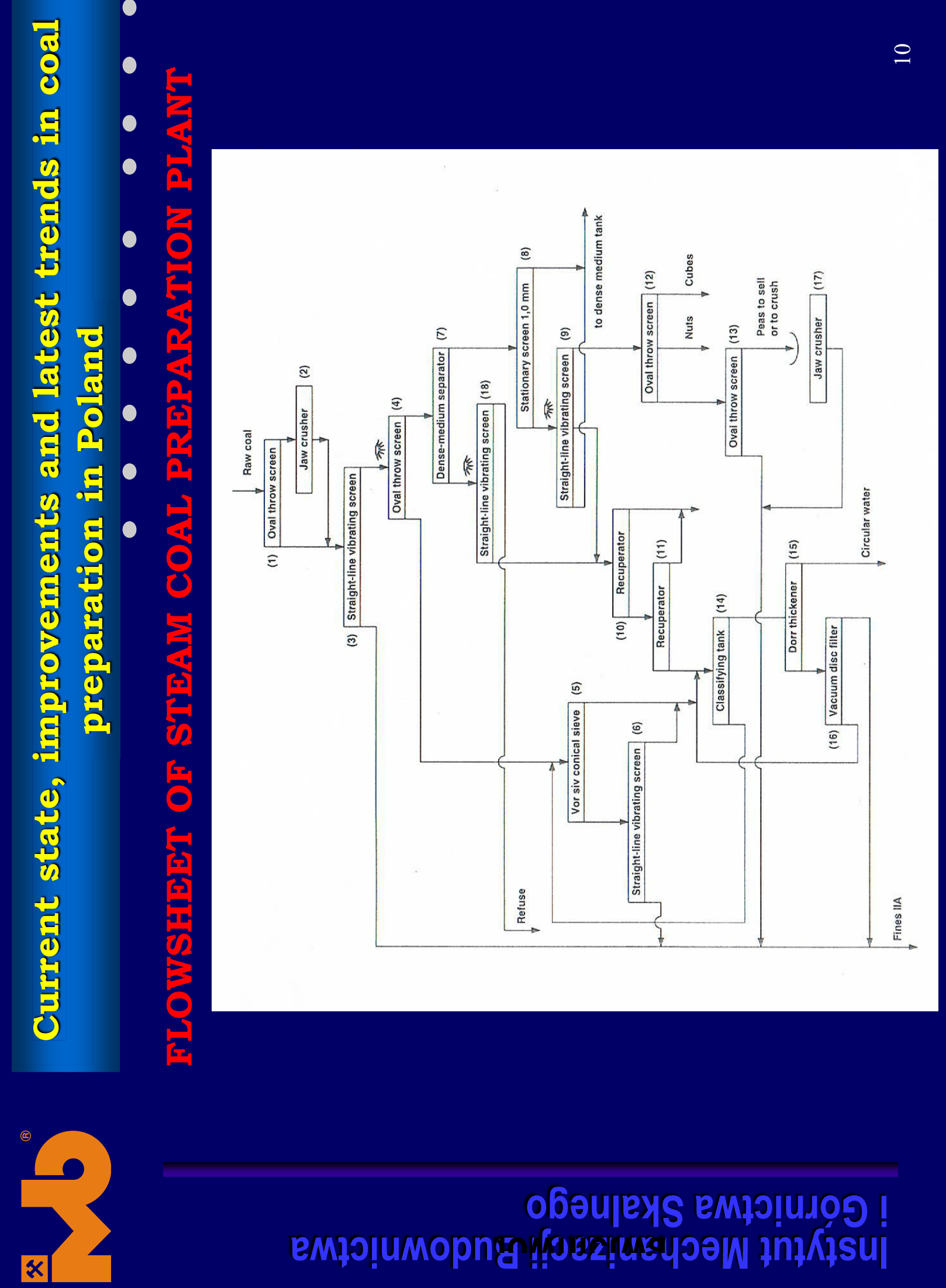

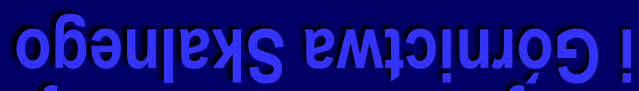

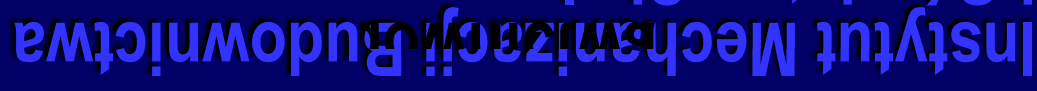




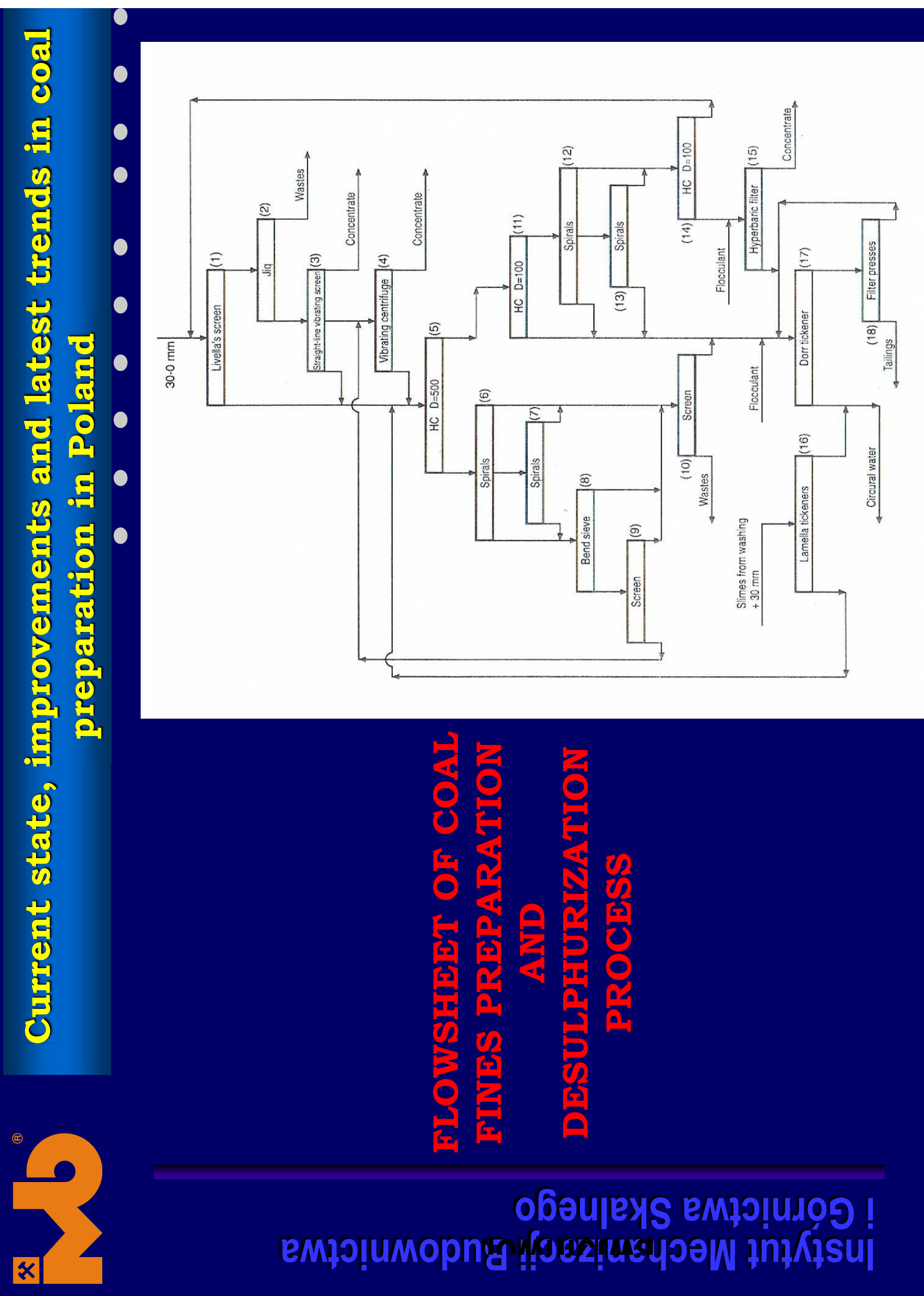



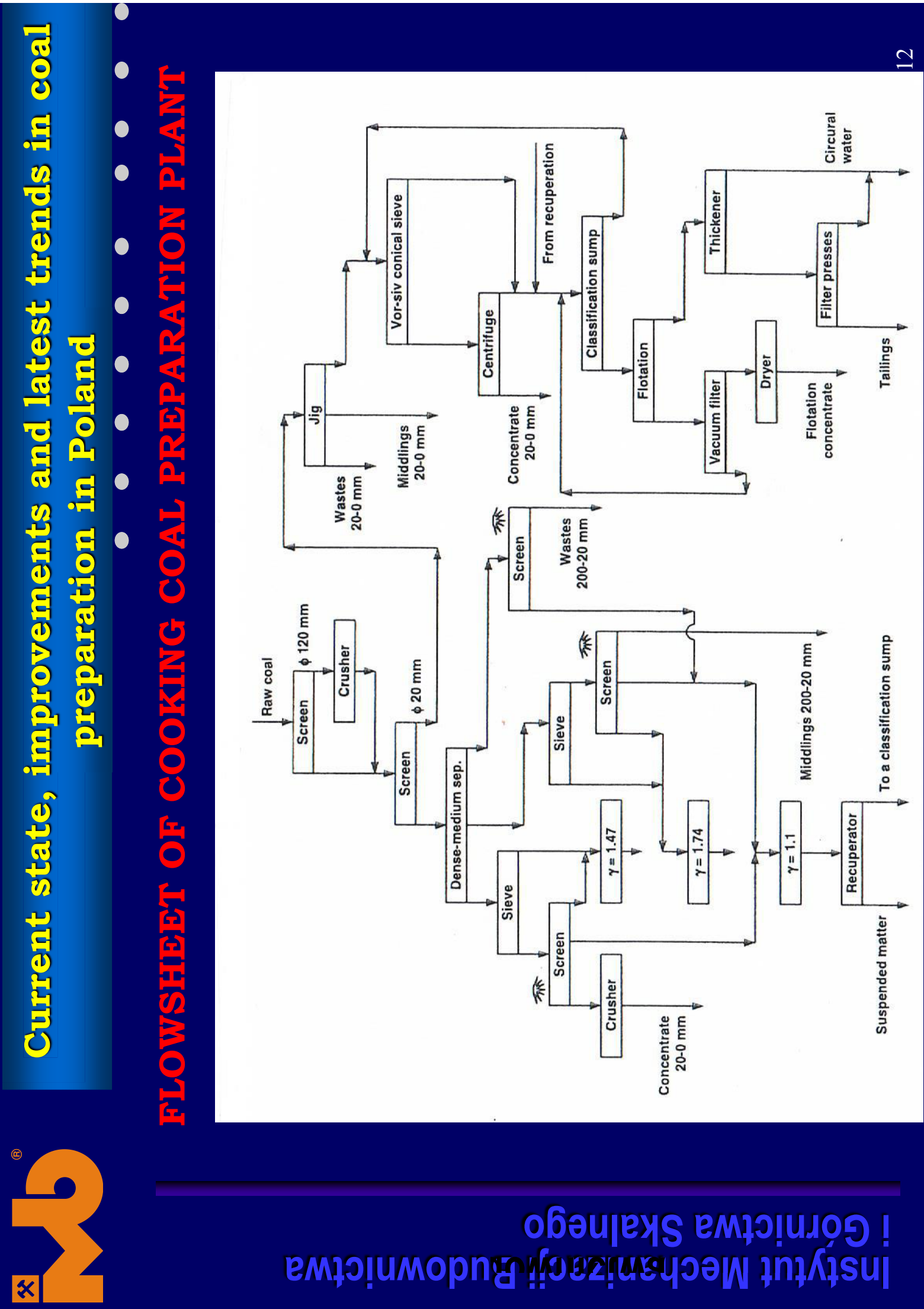

obəuाexs empo!uno? !

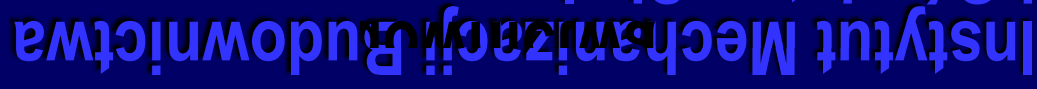




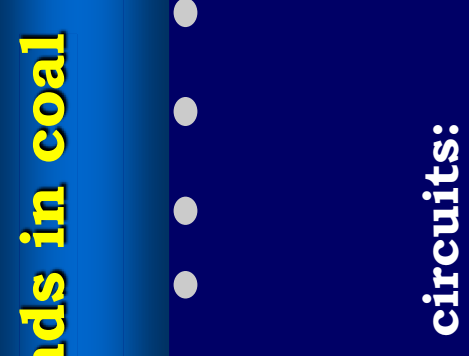

(1) 0

(1) -6

당 0

बi

ㄷ) 0

텅 요

(0) 덩

20 व

받 엉 0

(1) 0

단 둥

(1)

(1) 넉

$\rightarrow 0$

- 1

닉 (1)

읭 능

of

क)

(3)

荡

늘

(1)

늘

उ)

类
불

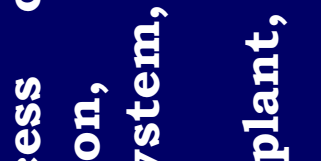

$8 \%$

要

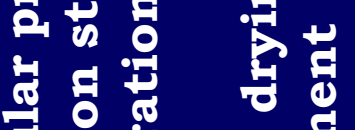

웅 용

要

嵒 。

诺

붕 영 웡

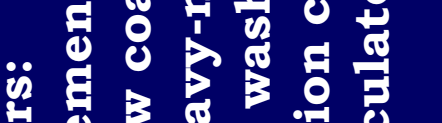

急

웅

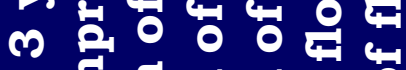

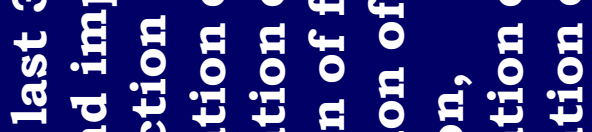

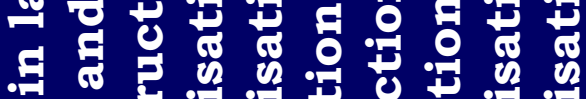

is 5

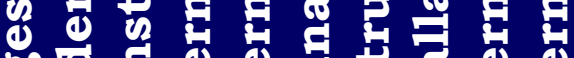

언

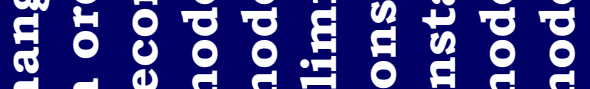

동

G 80. . . . .

g

c)

药

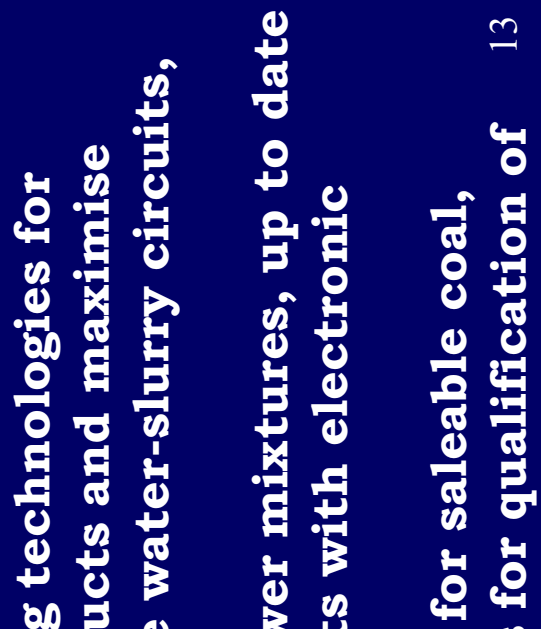

8 :

․

(c) 웅 운

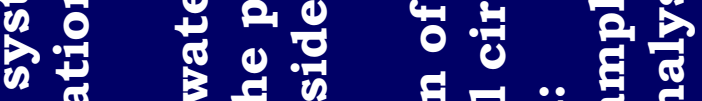

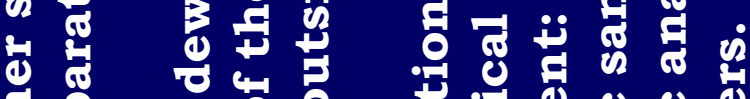

웅

+

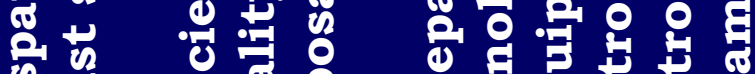

- य क 2 क

- 5 엉

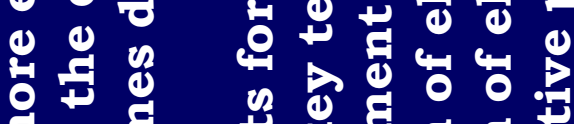

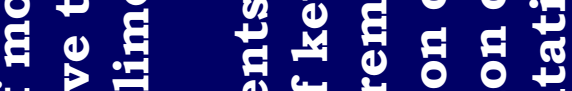

48 붕

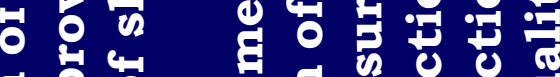

당

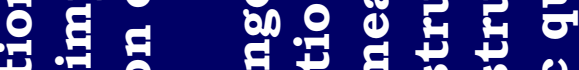

$\rightarrow 00$ 웡 0

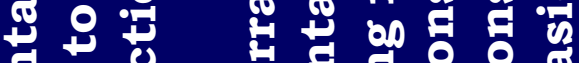

(1)

$\theta$

(1) 0

웅

自案

A
동

(1)

- is

읍
아의 


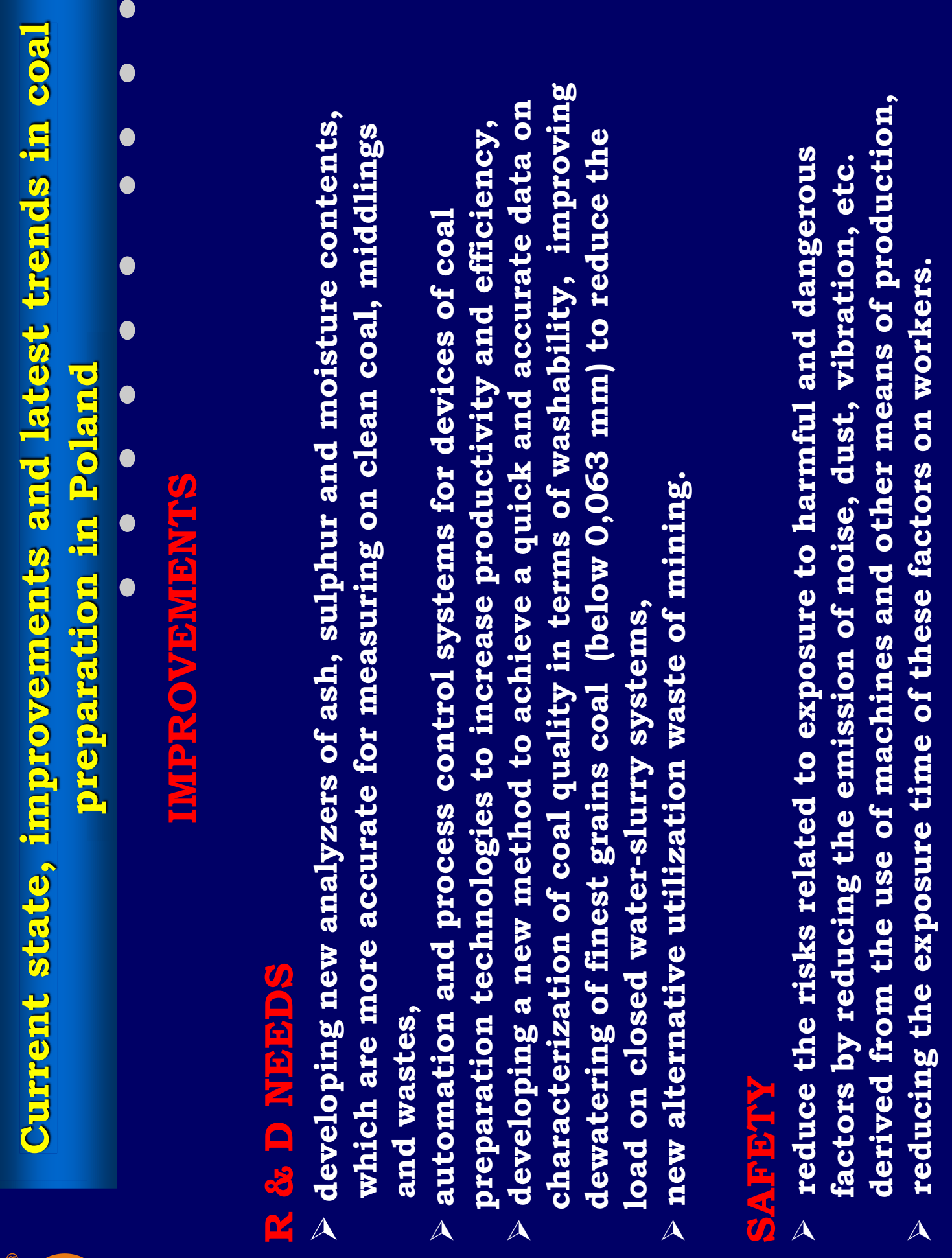




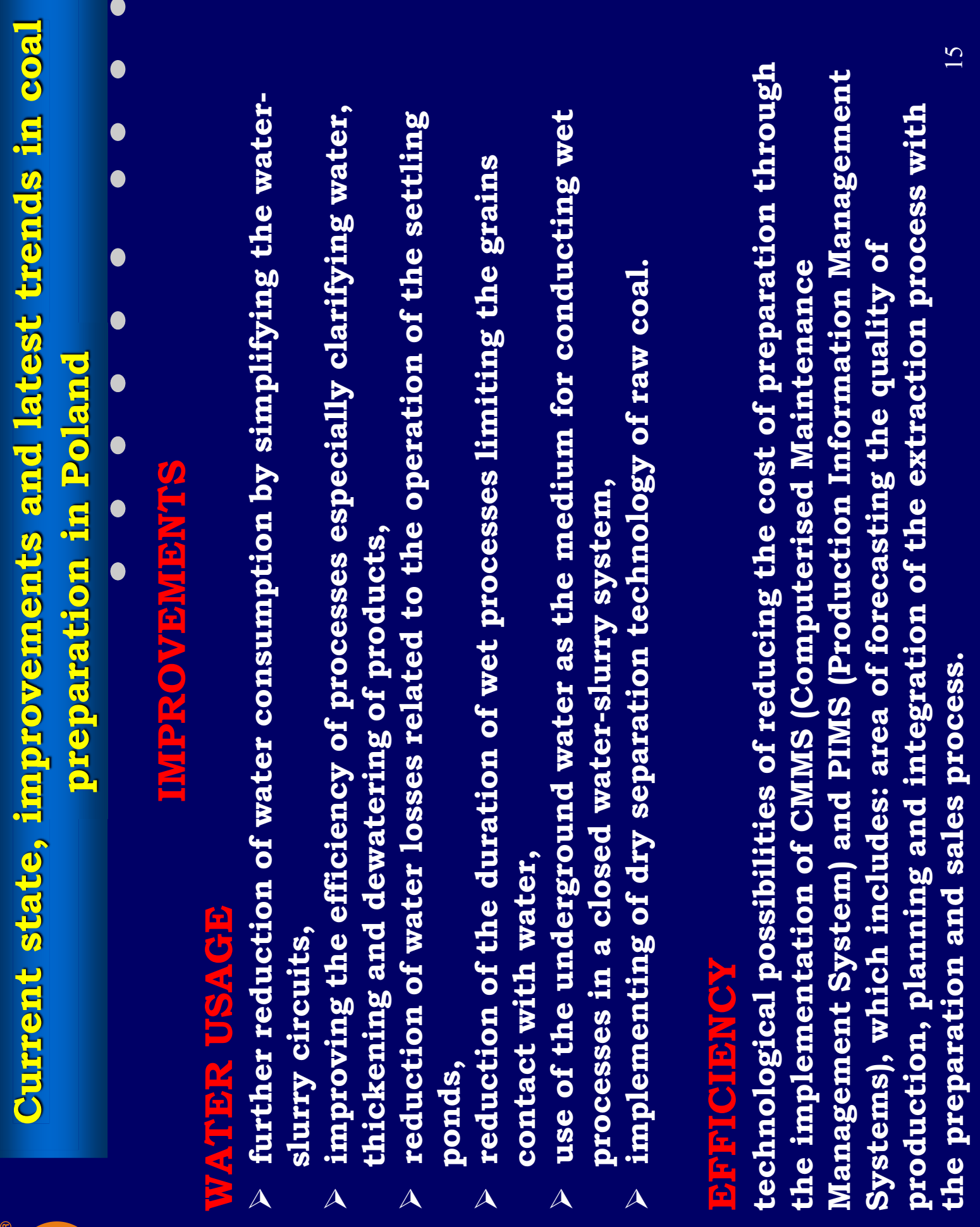




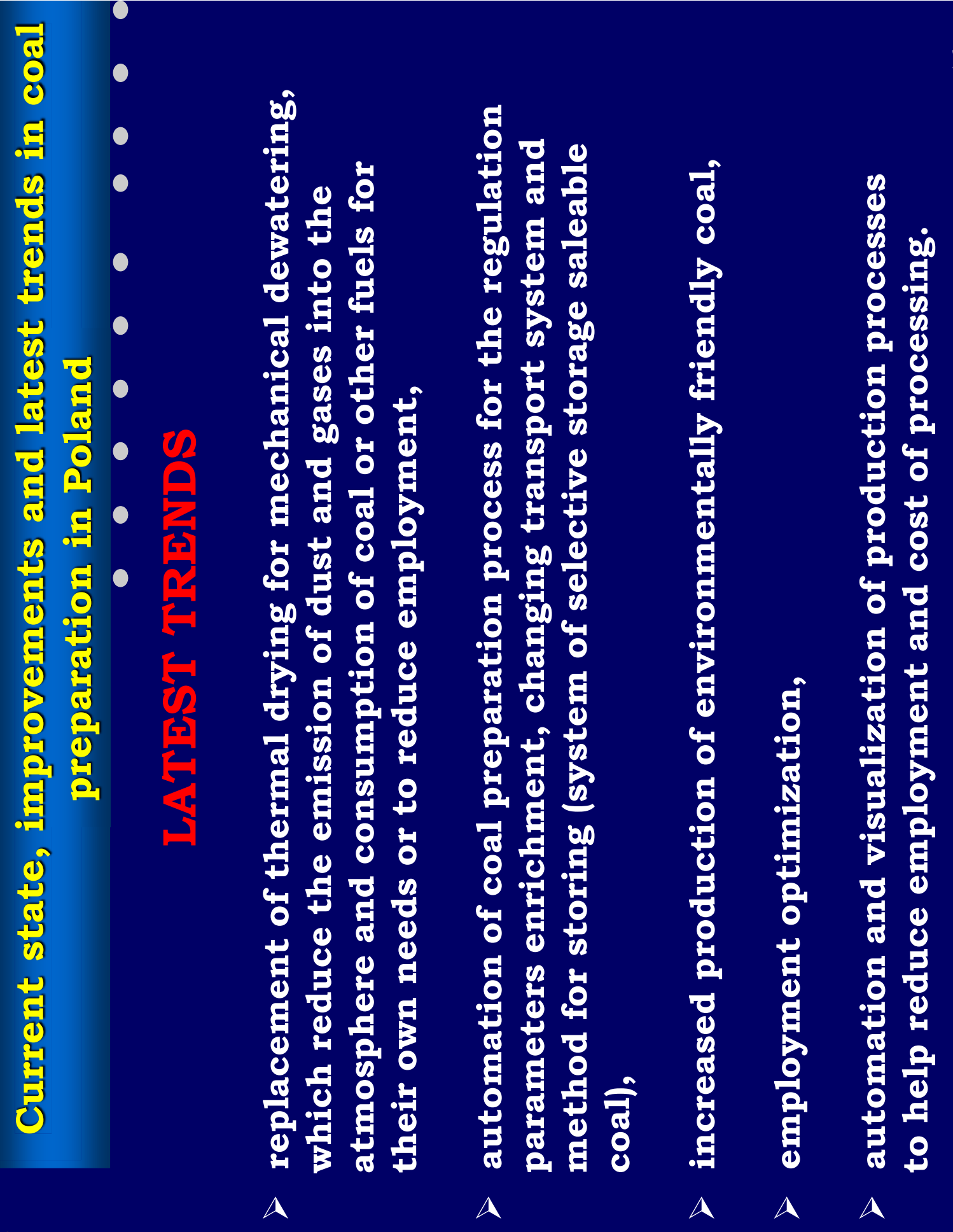



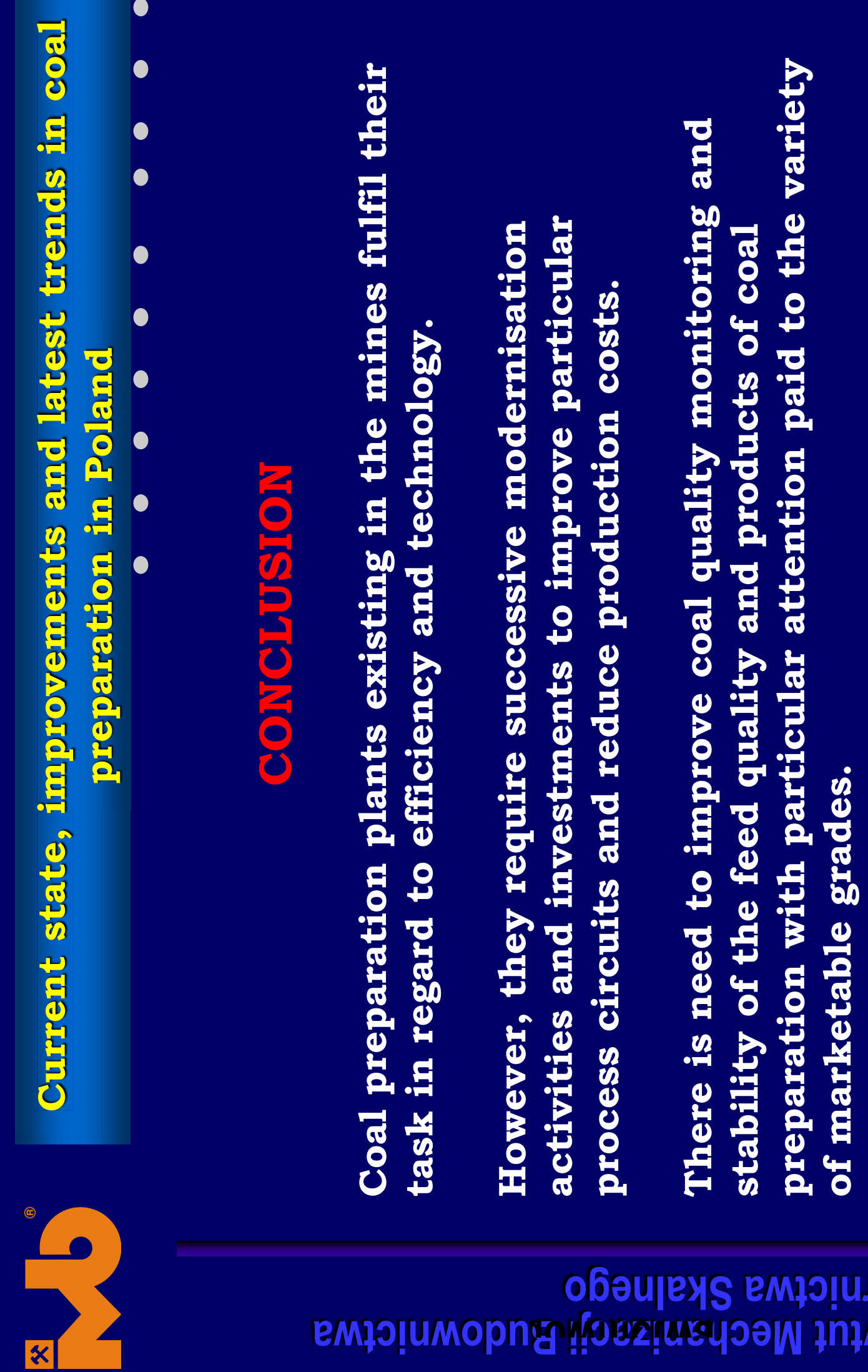

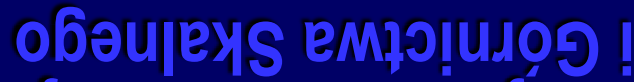

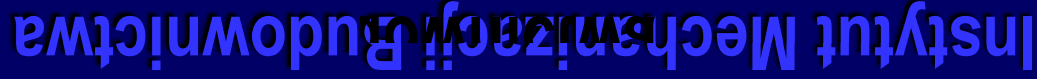




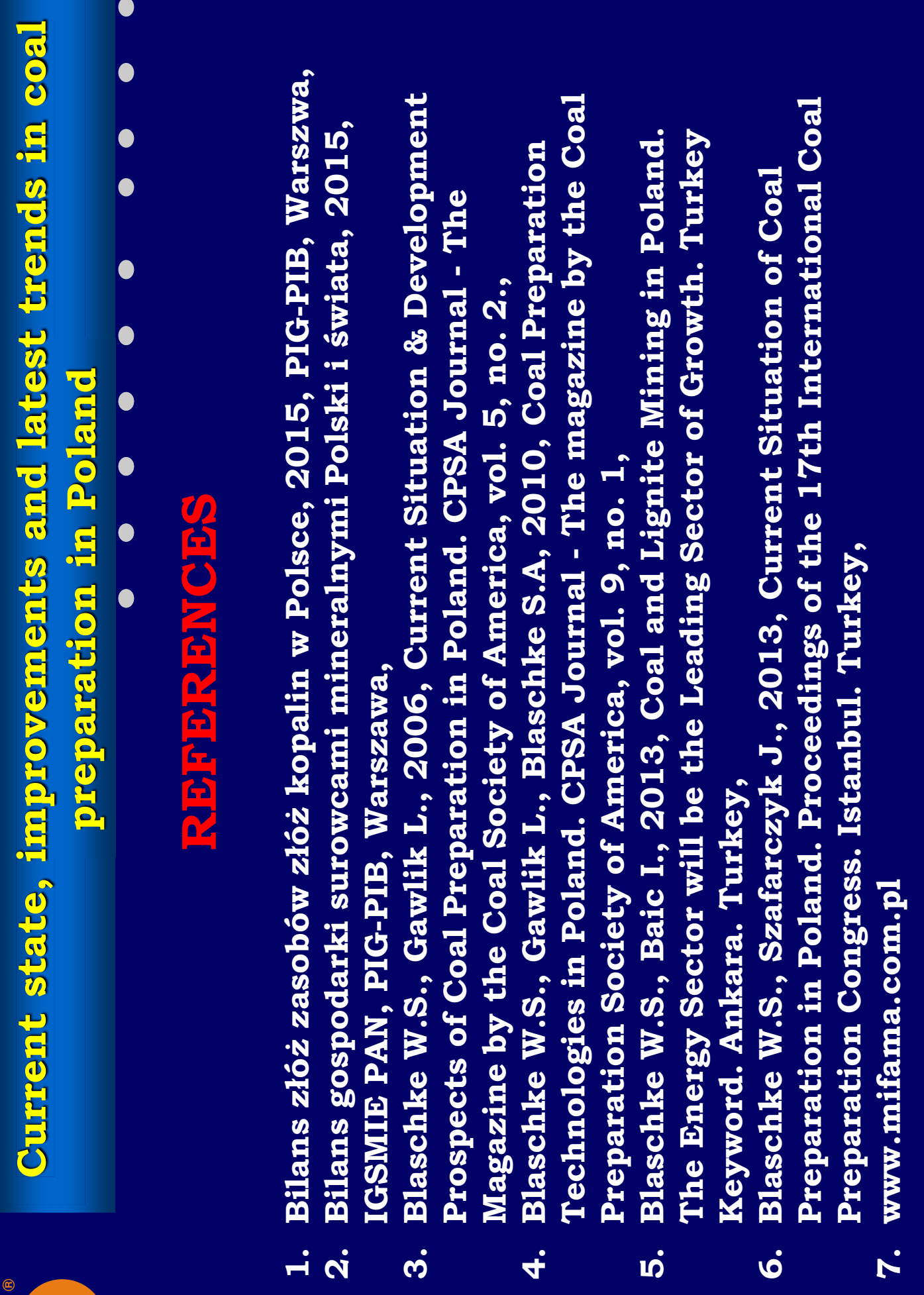




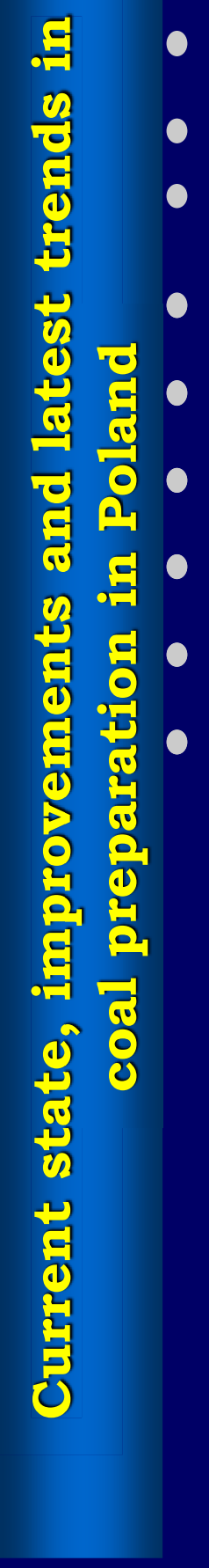

\&ै

(4)

氙 $\begin{array}{ll}0 \\ 0\end{array}$

군

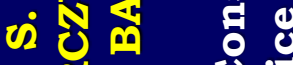

3 过

전

요

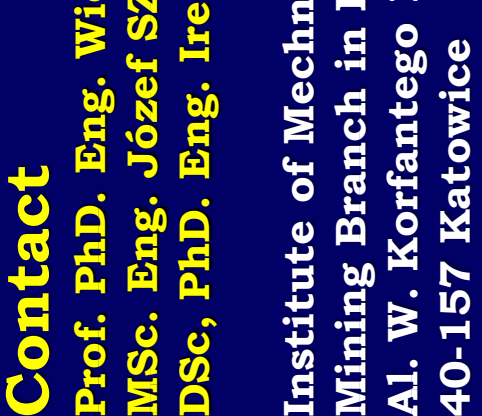

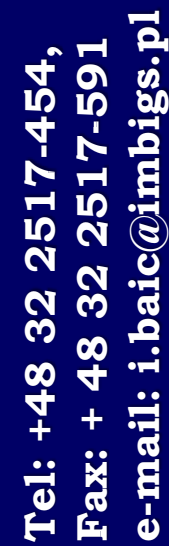

U)

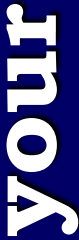

일
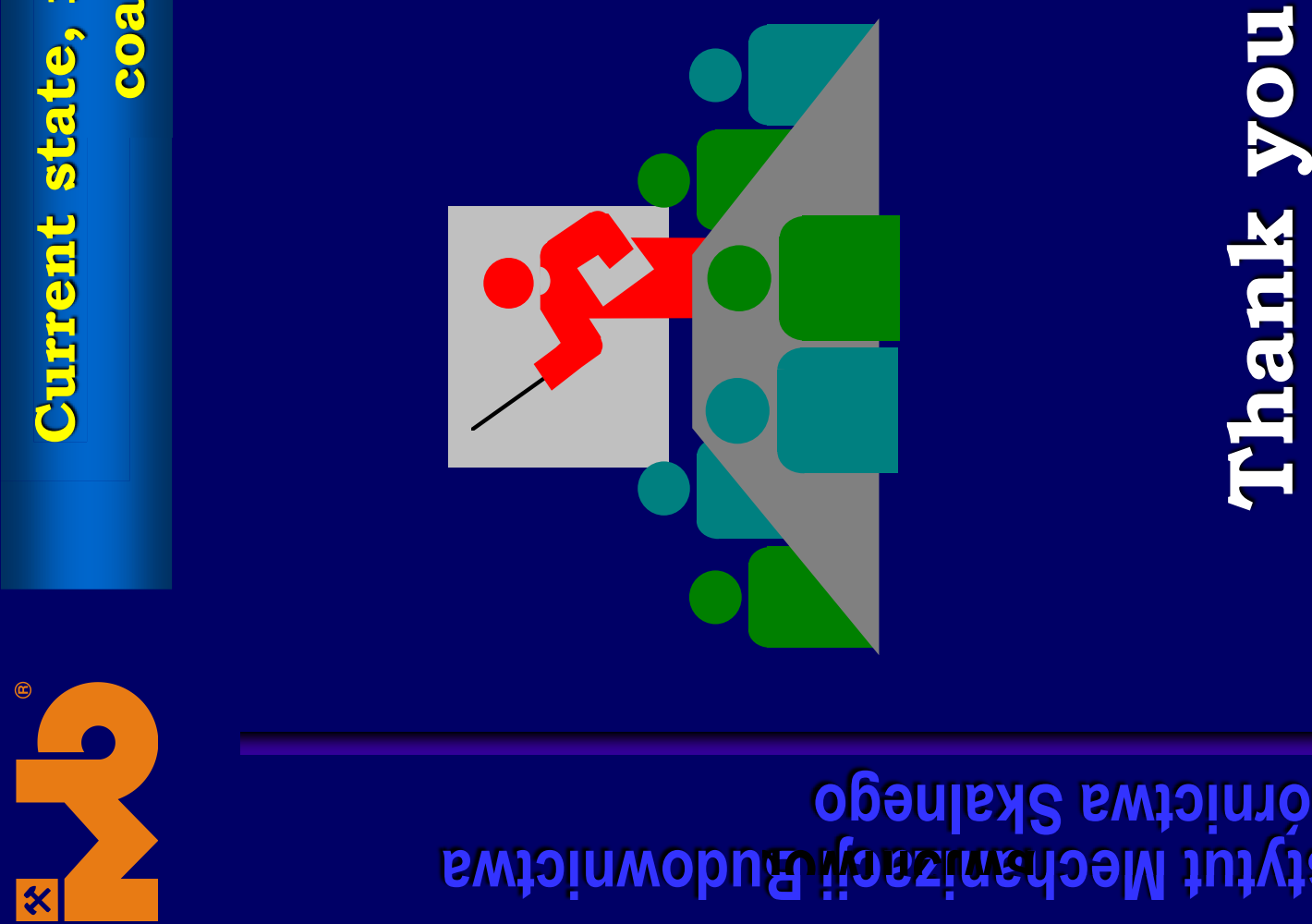